\title{
Production of proteolytic extract by Aspergillus oryzae grown by solid state fermentation using canola meal as substrate
}

\author{
Natália Lima de Oliveira Pascoal ${ }^{1 *}$, Suzanne Alves Cordeiro², Gustavo Adolfo Saavedra Pinto ${ }^{2}$ \\ From 5th Congress of the Brazilian Biotechnology Society (SBBIOTEC) \\ Florianópolis, Brazil. 10-14 November 2013
}

\section{Background}

Proteases are enzymes used in diversified process and industrial products, where the most important is the food sector and the detergent fabrication. The microbial obtention way is the most relevant, and the filamentous fungi are the main synthesis agents in industrial scale. [1]. The genres Conidiobolus, Verticillium, Penicillium e Aspergillus are reported as proteases producers. The specie Aspergillus oryzae is considerate not toxicogenic and it is a huge proteases producer, so it has an elevated industrial interest $[2,3]$. The literature about this theme is vast, there are countless articles using the Aspergillus in semi-solid fermentative processes to proteases of obtention. Nevertheless, the importance of this work was demonstrated by the use of an alternative substrate to protease synthesis, the canola meal. The canola meal it is a byproduct of the extraction process of canola oil, showing high protein content. Nowadays, the industrial sector has encouraged researches that can contribute and adding value to this residue [3]. So, in this context, this work proposed to evaluate preliminarily the performance of five lines of Aspergillus oryzae in relation to the production of proteases in semi-solid fermentation using the canola meal as a substrate inductor.

\section{Methods}

Five NRRL strains of Aspergillus oryzae (designated 2220, $1911,5590,694$ e 2217) were used in these experiments. For the solid state fermentation was used a medium of canola meal at proportion of $100 \mathrm{~g}$ of bran to $40 \mathrm{~mL}$ of water. The experiments was done in Erlenmeyers of $500 \mathrm{~mL}$, each flask contained $40 \mathrm{~g}$ of medium, previously

${ }^{1}$ Ceará State University, RENORBIO, Fortaleza, CE, Brazil

Full list of author information is available at the end of the article autoclaved. The initial inoculum was of $10^{7}$ spores.g $^{-1}$ of fermentation medium. The fermentations were performed in statics conditions under temperature of $20^{\circ} \mathrm{C}$ during 96 hours. The proteolytic activity was determined each 24 hours using azocasein as substrate and trichloroacetic acid as precipitating agent. A unit of proteolytic activity was defined as a quantity of enzyme that produces a difference of 0.01 of absorbance per minute of reaction between the reactional blank and the samples in the experimentals conditions. The results were expressed in ${\mathrm{U} . \mathrm{g}^{-1}}$ of fermentation medium [5]. The statistical analysis, through the Scoot-Knott test was performed.

\section{Results and conclusions}

Within 48 hours of fermentation, all extracts showed proteolytic activity, indicating that all strains were able to synthetise proteases. The highest levels of activity were reach at 72 hours of fermentation and no difference was observed after this period. It was observed that $A$. oryzae NRRL 2217 and NRRL 2220 were protease best producers. The proteases production profile of the canola bran was similar to that demonstrated by Thanapimmetha [4], with Jatropha curcas residue medium. This study shows the viability of using the canola meal to the synthesis of proteases by differents strains of $A$. oryzae.

\footnotetext{
Authors' details

${ }^{1}$ Ceará State University, RENORBIO, Fortaleza, CE, Brazil. ${ }^{2}$ National Research Center of Tropical Agroindustry, Embrapa, Fortaleza, CE, Brazil.

Published: 1 October 2014

References

1. Hernández-Martínez R, Gutiérrez-Sánchez G, Bergmann CW, Loera-Corral L, Rojo-Domínguez A, Huerta-Ochoa S, Regalado-González C, PradoBarragán LA: Purification and characterization of a thermodynamic stable
} 
serine protease from Aspergillus fumigates. Process Biochemistry 2011, 46:2001-2006, doi.org/10.1016/j.procbio.2011.07.013.

2. Ward OP: Industrial Biotechnology and Commodity Products.Proteases. In In Comprehensive Biotechnology. Volume 3.. 2nd edition. University of Waterloo, Canada; 2011: 571-582, doi:10.1016/B978-0-08-088504-9.00222-1.

3. Aluko RE, Mclntosh T: Limited enzymatic proteolysis increases the level of incorporation of canola proteins into mayonnaise. Innovative Food Science \& Emerging Technologies 2005, 6(2):195-202, doi.org/10.1016/j. ifset.2004.11.003.

4. Thanapimmetha A, Luadsongkram A, Titapiwatanakun B, Srinophakun P: Value added waste of Jatropha curcas residue: Optimization of protease production in solid state fermentation by Taguchi DOE methodology. Industrial Crops and Products 2012, 37:1-5.

5. Charney J, Tomarelli RM: A colorimetric method for the determination of the proteolytic activity of duodenal juice. Journal of Biological Chemistry 1947, 170(23):501-505.

doi:10.1186/1753-6561-8-S4-P177

Cite this article as: Oliveira Pascoal et al:: Production of proteolytic extract by Aspergillus oryzae grown by solid state fermentation using canola meal as substrate. BMC Proceedings 2014 8(Suppl 4):P177.

\section{Submit your next manuscript to BioMed Central} and take full advantage of:

- Convenient online submission

- Thorough peer review

- No space constraints or color figure charges

- Immediate publication on acceptance

- Inclusion in PubMed, CAS, Scopus and Google Scholar

- Research which is freely available for redistribution

Submit your manuscript at www.biomedcentral.com/submit
Biomed Central 